\title{
The Development of Tamansiswa in the Global Era
}

\author{
Endang WK ${ }^{1}$, Enggar Kartikasari², Rina Setyaningsih ${ }^{3}$, Desy Triinayah ${ }^{4}$ \\ \{endang.karyaningsih@ustjogja.ac.id¹, enggarkartikasari@ustjogja.ac.id², \\ rina.setyaningsih@ustjogja.ac.id3, desytri@ustjogja.ac.id4 \} \\ Departement of PKK Sarjanawiyata Tamansiswa University, Indonesia 1234
}

\begin{abstract}
Tamansiswa is an educational institution that builds communities to realize a peaceful order of peace and happiness. In the global era Tamansiswa actually suffered a setback with indications that many Tamansiswa branches were closed because there were no interested registrans. Education in the global era wants to be able to form a democratic Indonesian society. This demand can be answered by Tamansiswa by applying among the methods that can produce students who have an independent spirit. Tamansiswa can survive and compete by applying the principles of Tamansiswa and Pancadharma whose implementation is in accordance with the development of nature and the times.
\end{abstract}

Keywords: Tamansiswa, The Global Era.

\section{Introduction}

Tamansiswa is a cultural and development for society that uses education as a means to realize a peaceful and peaceful orderly. Tamansiswa was founded by Ki Hadjar Dewantara (KHD) as an effort to gain independence for the Indonesian people. KHD thinks that stive for independence by taking up arms against the Dutch government cannot succeed, so it must be done in another way, KHD did to achieve independence is to establish an educational institution, Tamansiswa. Tamansiswa was established with the aim of educating the Indonesian peoples. KHD believes that this nation's education can be separated from colonialism. KHD believes that education is an effort to promote, liberate, and prosper the nation. KHD said that "people's power is the amount of strength of each member of the people, all efforts to uphold the nation's degree will not succeed if it does not start from the bottom. The people who are strong will be proficient to create necessary effort and useful for the prosperity of the country" [1].

Tamansiswa was established on July 3, 1922. The community welcomed enthusiastically because Tamansiswa became a school that could accept indigenous groups to study. Community acceptance was shown by the many opening of Tamansiswa branches in various regions in just six months after Tamansiswa was established. To make it easier to coordinate the Tamansiswa branches, the Tamansiswa Association was formed based in Yogyakarta which was marked by Candra Sengkala Suci Tata Ngesti Tunggal.

Tamansiswa was founded with a noble goal of educating and educating the life of the nation to escape colonialism. This condition made the Dutch colonial government unhappy, so the Dutch made a law Onderwij Ordonansi or a wild school with the intention of closing 
Tamansiswa. Knowing the law KHD is against and rejecting. KHD's rejection received support from community leaders so that the Dutch Government canceled the law.

Community support for Tamansiswa shows that Tamansiswa is in the hearts of all Indonesians. Tamansiswa is in demand by many people, but now what happened to Tamansiswa? Tamansiswa's branches have closed a lot because there are no more students. Kompas daily edition 2 May 2012 reported that 300 schools in Tamansiswa were suspended [2]. "Tamansiswa schools have difficulty supporting themselves, even some schools are completely closed because there are no students". According to Sunarno Tamansiswa students began to be abandoned when parents looked more at schools that put forward the religious curriculum. Harian Jogja edition 14 May 2012 also made the title of the article "Tamansiswa Increasingly Critical condition" which reported that a number of Tamansiswa schools were forced to close due to lack of funds and lack of students [3]. A source from Tamansiswa Jetis Middle School said that Tamansiswa school was a workshop because it received waste that was considered unfit for study in its original school. Some of these figures show that the condition of Tamansiswa school is quite alarming, even though the Tamansiswa school was founded by KHD with full struggle in the colonial situation.

\section{Preliminary}

Society that uses education as a means to realize a peaceful and peaceful orderly. Tamansiswa was founded by Ki Hadjar Dewantara (KHD) as an effort to gain independence for the Indonesian people. KHD thinks that stive for independence by taking up arms against the Dutch government cannot succeed, so it must be done in another way, KHD did to achieve independence is to establish an educational institution, Tamansiswa. Tamansiswa was established with the aim of educating the Indonesian peoples. KHD believes that this nation's education can be separated from colonialism. KHD believes that education is an effort to promote, liberate, and prosper the nation. KHD said that "people's power is the amount of strength of each member of the people, all efforts to uphold the nation's degree will not succeed if it does not start from the bottom. The people who are strong will be proficient to create necessary effort and useful for the prosperity of the country" [1].

Tamansiswa was established on July 3, 1922. The community welcomed enthusiastically because Tamansiswa became a school that could accept indigenous groups to study. Community acceptance was shown by the many opening of Tamansiswa branches in various regions in just six months after Tamansiswa was established. To make it easier to coordinate the Tamansiswa branches, the Tamansiswa Association was formed based in Yogyakarta which was marked by Candra Sengkala Suci Tata Ngesti Tunggal.

Tamansiswa was founded with a noble goal of educating and educating the life of the nation to escape colonialism. This condition made the Dutch colonial government unhappy, so the Dutch made a law Onderwij Ordonansi or a wild school with the intention of closing Tamansiswa. Knowing the law KHD is against and rejecting. KHD's rejection received support from community leaders so that the Dutch Government canceled the law.

Community support for Tamansiswa shows that Tamansiswa is in the hearts of all Indonesians. Tamansiswa is in demand by many people, but now what happened to Tamansiswa? Tamansiswa's branches have closed a lot because there are no more students. Kompas daily edition 2 May 2012 reported that 300 schools in Tamansiswa were suspended [2]. "Tamansiswa schools have difficulty supporting themselves, even some schools are completely closed because there are no students". According to Sunarno Tamansiswa students began to be abandoned when parents looked more at schools that put forward the religious 
curriculum. Harian Jogja edition 14 May 2012 also made the title of the article "Tamansiswa Increasingly Critical condition" which reported that a number of Tamansiswa schools were forced to close due to lack of funds and lack of students [3]. A source from Tamansiswa Jetis Middle School said that Tamansiswa school was a workshop because it received waste that was considered unfit for study in its original school. Some of these figures show that the condition of Tamansiswa school is quite alarming, even though the Tamansiswa school was founded by KHD with full struggle in the colonial situation.

\section{Discussion}

\subsection{Tamansiswa}

\subsubsection{Understanding}

Tamansiswa is a cultural and development struggle for society that uses education in a broad sense to realize a peaceful order of peace and greetings. Education is indeed an effort to struggle to build society towards glory. Development is to build Indonesian people entirely.

\subsubsection{Vision, Mission and Purpose of Tamansiswa}

To go towards that development, Tamansiswa has a vision, mission and purpose (Bitus, 2010:1).

\section{Vision:}

The realization of an orderly society of peace, greetings and happiness according to the just prosperous society based on Pancasila. Peaceful and orderly society is a community that has a family spirit and passion for mutual cooperation, there is no oppression, each individual can enjoy an independent life in a harmonious common life. Greetings and happiness are human beings who can feel fulfilled by all the necessities of life, material, spiritual, and social life.

Tamansiswa's efforts in realizing his vision are:

1) Organizing education both school education and non-school education

2) Preserve and develop culture through education

3) Organizing socio-economic business. (Bitus, 2010)

Tamansiswa's goal is to realize the ideals of humanity and the ideals of Indonesian independence and to create a peaceful orderly society and happy greetings, in accordance with an independent, sovereign, united, just and prosperous society based on Pancasila and the 1945 Constitution.

\section{Mission:}

1) Preserve and develop Indonesia's national culture

2) Creating an orderly society of peace, greetings and happiness in harmony with a just and prosperous society based on Pancasila.

Educate the life of the nations, creativity, sense, and initiative towards the development of free human being born and inward, noble character and high human dignity and dignity.

\subsubsection{Principles, Foundation and Characteristics of Tamansiswa}

The Tamansiswa principle is Pancasila. Tamansiswa's foundation is the 1922 Tamansiswa Principle which contains seven teachings. Tamansiswa's characteristics are Pancadharma which includes nature, independence, culture, nationality, humanity. 


\subsection{Global Era Education}

In this globalization era competition, victory is determined by the quality of Human Resources (HR). The quality of human resources itself is determined by good quality education at the primary, secondary and high levels. The era of globalization is characterized by the characteristics of mutual openness and dependence between countries. To answer the challenges and opportunities of global life, a new paradigm of education is needed.

\subsubsection{Characteristics of Global Era Education}

Tilaar (2000:19-23) put forward the main points of the new paradigm of education as follows. [3].

1) Education is aimed at forming a new democratic Indonesian society

2) Democratic societies need education that can foster democratic individuals and societies

3) Education is directed at developing behaviors that respond to internal and global challenges

4) Education must be able to direct the birth of a united and democratic Indonesian nation

5) In facing a competitive and innovative global life, education must be able to develop the ability to compete in the framework of cooperation

6) Education must be able to develop diversity towards the creation of an Indonesian society united in the diversity of society's wealth

7) Education must be able to Indonesize Indonesian society so that every Indonesian person feels proud to be an Indonesian citizen.

3.2.2 Education and Civil Society

Education has a very strategic role in supporting and accelerating the formation of a democratic democratic society which is one of the most important characteristics of Indonesian civil society. The role of education is to prepare the nation's children both individually and socially in order to have the ability, skills, ethos and motivation to participate in civil society, the public order of Indonesian civil society contains the following characteristics. (Azyumardi, 2002).

1) A community that is faithful and devoted to God

2) An impartial democratic society that values diversity and diversity.

3) Communities that recognize and uphold human rights

4) An orderly and law-conscious society

5) Communities who are part of the global community who have the skills and skills.

6) Society that upholds noble values

7) Learning communities that grow from the community, by the community and for society.

From the characteristics of educational demands of the global era, it can be concluded that the people expected today are people who are devoted, orderly, democratic, respect differences, uphold noble values, and have skills.

As KHD said that "education is a development effort. Education that is carried out with conviction, directed towards human safety and happiness, is not only a practice of development, but a struggle too.

Education means maintaining life-growth towards progress. "Education is a cultural endeavor, based on civilization, which is to advance life so as to enhance humanity."The KHD said can be interpreted as an effort to advance life and enhance humanity must be fought forever, Tamansiswa must continue to live in the hearts of the Indonesian people, including in this global era. 
Tamansiswa has a principle, a foundation of struggle and characteristics. The principle of Tamansiswa is Pancasila, the foundation of its struggle is the principle of Tamansiswa 1922, and the characteristic of Tamansiswa is Pancadharma. When observed, the foundation of the struggle and the characteristics of Tamansiswa are never outdated. The Tamansiswa and Pancadharma principles remain in line and can answer educational needs in this global era.

Education in the global era wants to be able to form a democratic Indonesian society. This demand answered by applying the "among methods". "The Among methods" will produce students who have an independent spirit. The Independence spirit according to Tamansiswa is self-independence which is limited by the independence of others, meaning that everyone has the right to do something but by remembering the orderly peace of society. If these conditions are realized and carried out by everyone, a democratic society will be achieved.

Education in the global era wants to be able to form a democratic Indonesian society. This demand answered by applying the "among methods". "The Among methods" will produce students who have an independent spirit. The Independence spirit according to Tamansiswa is self-independence which is limited by the independence of others, meaning that everyone has the right to do something but by remembering the orderly peace of society. If these conditions are realized and carried out by everyone, a democratic society will be achieved.

Global education era also requires the creation of an Indonesian society that is united above the diversity of people's wealth. This claim can be answered by Tamansiswa. Isn't Tamansiswa having Pancadharma in which there is culture and nationality? Culture implies the necessity to maintain the values and forms of national culture. In maintaining the national culture, the first and foremost is to bring national culture towards the progress of the nation in the interests of the lives of the people born and inner according to the development of nature and its era.

Culture is intended to nurture and develop a culture in Indonesia that is multicultural with the "Trikon Theory" of continuous, convergent, and concentric. The "Trikon Theory" can be used as a guide for us (the nation) in regulating social life in national relations and relations with the international community. Nationality means that there is a sense of one nation in joy and happiness, and as well as the desire to achieve happiness in the life of the whole nation. The basis of happiness must not be contrary to the basis of humanity, it must even be the nature, form and behavior of a real human being, and do not contain hostility towards other nations. In order to encounter the global era Tamansiswa does not need to feel worried and feel left behind. The teachings in Tamansiswa's principles and Pancadharma can answer the challenges of this era in the global era. All things that become the educational paradigm of the global era can be answered by Tamansiswa. It must be considered is how the Tamansiswa managers respond and take wise steps so that Tamansiswa will return to the hearts and interests of all Indonesian peoples. In our opinion that must be addressed first is the condition both physically and non-physically. The physical meaning is the condition of the building and the environment while the non-physical are human resources. We do not need to accuse that there is a reduction in the number of students in Tamansiswa because the government opens schools for free, or considers parents to prefer religion-based schools. As long as Tamansiswa is well managed, people will come by themselves.

The learning environment is very influential on the condition of students. A good environment can provide students with comfort and tranquility in learning. Tamansiswa must really be a park where everyone in it feels comfortable, happy, and feel proud. Love and pride in Tamansiswa must be embedded in students and their parents. Some Tamansiswa schools still have a less clean environment, which is not reflected in the park at all. This requires awareness from the school manager to organize the environment.

As stated above, Tamansiswa schools often become workshops for waste children from other schools that are considered inappropriate in their home schools. Tamansiswa indeed has 
to educate all the nation's children, but if Tamansiswa is always a workshop for waste children, especially in schools where they don't go to class and in Tamansiswa they can enter the next level, Tamansiswa school will be considered as a school that is not qualified, has no self-esteem. In this case the Tamansiswa schools must be firm and need to apply discipline to all. I think it is better to educate a few students with good management so as to produce good graduates and get awards in the.

In the case of teaching Tamansiswa it must be adjusted to the times. In my opinion, the teaching in Tamansiswa is not left behind, it actually has the added value of noble character. Tamansiswa does not need to be carried away by the westernized learning because the learning is not in accordance with the principle of Tamansiswa. KHD wants Indonesian culture to be used as a way to find new livelihoods that are in harmony with our nature, with our nation. Arts education which is the flagship of Tamansiswa must still be maintained even if necessary for all levels of education.

The author argues that if improvements are really made, Tamansiswa will be visited again by prospective students, and when the prospective student arrives at Tamansiswa, Tamansiswa will remain alive and dare to compete in this global era. To support this effort, the improvement of the quality of human resources must also be a concern. Sri Edi Swasono (Chairperson of the Luhur Tamansiswa Council) said "Even though conditions are increasingly critical there are still many teachers who try to maintain the existence of Tamansiswa. Dedication of the teachers at Tamansiswa deserves thumbs up". If the teachers persist in Tamansiswa to serve, then they deserve to be appreciated. Teachers who get an award sufficiently can work calmly, can create a quality academic climate and can produce quality graduates as well.

\section{Conclussions} drawn.

Based on a description of education in the global era, the following conclusions can be

4.1 Education in the global era requires the existence of a new Indonesian society that is democratic, able to develop diversity, able to Indonesize Indonesian society so that every Indonesian person feels proud to be an Indonesian citizen.

4.2 Tamansiswa and Pancadharma principles can be able to answer the demands of education in the global era so that Tamansiswa will stay alive and dare to compete in the global era.

4.3 Need an effort to maintain the existence of Tamansiswa in the global era.

4.4 Physical and non-physical improvement is needed in the Tamansiswa neighborhood

\section{References}

[1] Bhekti 2012. Suryani. Tamansiswa Kian http://www.harianjogja.com/baca/2012/05/14/pendidikan-taman-siswa-kiankritis-185612. Diakses tanggal 24 Desember 2014.

[2] Majelis Luhur Persatuan Tamansiswa. 2013. Piagam dan Peraturan Besar Persatuan Tamansiswa.

[3] Ki Hadjar Dewantara, Pemikiran, Konsepsi, Keteladanan, Sikap Merdeka, (Pendidikan). 2013. Yogyakarta: UST-Press dan Majelis Luhur Persatuan

Tamansiswa. 
[4] Lusiana Indriasari. 2012. 300 Sekolah Perguruan Tamansiswa Mati Suri.http://edukasi.kompas.com/read/2012/05/02/21042475/300.Sekolah.Perguruan.Taman siswa.Mati.Suri . diakses tanggal 24 Desember 2014.

[5] Sri Edi Swasono, dalam Lusiana Indriasari. 2012. 300 Sekolah Perguruan Tamansiswa Mati Suri.

[6] http://edukasi.kompas.com/read/2012/05/02/21042475/300.Sekolah.Perguruan.Tamansi swa.Mati.Suri . 24 Desember 2014.

[7] Wiwik Kusdaryati. 2012. Paradigma Pendidikan di Era Global. http://download.portalgaruda.org/article.php?article=268400\&val=7109\&title=PAR

ADIGMA\%20PENDIDIKAN\%20DI\%20ERA\%20GLOBALISASI 6 Januari 2014.

[8] Lyons, S. (2004). An exploration of generational values in life and at work. ProQuest Dissertations and Theses, 441-441 . Retrieved from http://ezproxy.um.edu.my/docview/305203456?accountid=28930 